\title{
Reprodução medicamente assistida: paradoxo, ética e destino
}

\author{
Karine Xavier Cavalcante Ferreira $\mathbb{1}^{*}$ \\ Universidade Federal do Rio de Janeiro, Instituto de Filosofia e Ciências Sociais. Rio de Janeiro, RJ, Brasil
}

\begin{abstract}
Resumo: $\mathrm{O}$ objetivo deste artigo é construir um estudo comparativo entre a clínica psicanalítica e a médica, referente a quem elas se destinam, o paradoxo derivado de suas bases epistemológicas e o destino dado a este paradoxo. Trazemos para o contexto os discursos do campo clínico da medicina reprodutiva no Brasil, em especial o texto regulador das práticas de reprodução com materiais doados e duas críticas oriundas da esfera jurídica. Na primeira parte, a comparação entre métodos clínicos considera que, apesar do compartilhamento de bases epistemológicas comuns, as clínicas concebem, de formas distintas, a lógica de funcionamento daquele a quem destinam sua prática. Todavia a atual regulação das práticas clínicas de reprodução assistida expõe um paradoxo referente ao processo de filiação parental, que implica as bases epistemológicas médicas e psicanalíticas, com efeitos em suas práticas. Na segunda parte do artigo, compararemos os diferentes destinos dados a este paradoxo.
\end{abstract}

Palavras-chave: ciência, psicanálise, lógica, reprodução assistida, filosofia.

\section{Introdução}

Comparar a clínica psicanalítica com a clínica médica nos exige considerar as condições sob as quais as práticas surgiram. Partimos do princípio de que tais práticas clínicas compartilham uma mesma cosmovisão, uma "visão de mundo", ou, nas palavras de Freud, uma Weltanschauung científica (1933/2010), na qual é possível tomar o homem como objeto de investigação. Por meio desse conceito, podemos aproximar a clínica psicanalítica de uma perspectiva de continuidade, em relação à clínica médica, como sustentado na obra foucaultiana a partir dos anos 1960, ao contrário do que sustentava a tradição psicanalítica francesa de sua época (Birman \& Hoffmann, 2017). Essa perspectiva corresponde à continuidade do discurso da medicina que não nos impede de implicar (com Jacques Lacan) as diferenças em relação aos métodos, nem de apostar nos diferentes destinos dados ao que aparece como paradoxo nas duas operações.

A formalização do saber na Weltanschauung científica admite seu limite no que ainda não foi descoberto. A produção e o registro do saber refletem sua perspectiva positivista, na qual o acúmulo do saber coincide com o alcance da verdade. Essa formalização foi possível a partir cogito cartesiano (Lacan, 1965/1966), que ancora o homem na certeza de sua existência, afastando-o da cosmovisão religiosa e da relativização cética sobre a capacidade de se alcançar a certeza de sua existência. $O$ saber sobre sua verdade originária não o livra, porém, do encontro com certos paradoxos, ao passo da construção de seu saber.

\footnotetext{
* Endereço para correspondência: karineferreirapsi@outlook.com
}

Destacamos o código genético como a formalização de um saber sobre a verdade filiatória originária do homem, passível de controle, ou seja, uma filiação passível de autenticação científica, sem abster de antinomias as formações discursivas clínicas e jurídicas. Sua condição paradoxal aparece diante das múltiplas possibilidades de manipular a reprodução humana.

O paradoxo convida o clínico a dar os seguintes destinos ao seu ideal de objeto de estudo: a admissão de uma verdade paralela e, necessariamente, a reconsideração da estrutura lógica de funcionamento de seu objeto de análise, ou o encerramento de uma das premissas da antinomia, na condição de falsa. Esses destinos testemunham o movimento de construção do saber submisso à verdade que o causa (Lacan, 1965/1966).

\section{Sujeito da ciência, sujeito na clínica}

Consideramos este sujeito possível a partir do cogito cartesiano, quando escapa do ceticismo, pois encontra a certeza de sua existência e o porquê dela quando pensa sobre seu ato de pensar. ${ }^{1}$ O que permanece do sujeito cartesiano, através da Weltanschauung científica é a sua implicação no instante em que pensa racionalmente que pensa. O que dele existe além da certeza que pensa no momento em que pensa não é implicado, mantendo-o, portanto, sob a condição inevitavelmente dividida entre o momento em que sabe que existe e tudo o que está além deste momento. Diante dessa divisão, somos conduzidos

\footnotetext{
1 "Eu sou, eu existo: isto é certo; mas por quanto tempo? A saber, durante o tempo em que eu penso; pois talvez, pudesse ocorrer, se eu cessasse de pensar, que cessasse ao mesmo tempo de ser ou de existir" (Descartes, 1641/2005, p. 46); e: "Pois é contraditório julgar que o que pensa, no momento mesmo em que pensa, não existe. E, por conseguinte, este conhecimento eu penso, logo existo é, de todos, o primeiro e o mais certo a ocorrer a quem quer que filosofe com ordem" (Descartes, 1644/2002, p. 27).
} 
à impossibilidade de tudo representar, ou seja, os limites na construção de um discurso de si.

Em "Novas conferências introdutórias à psicanálise: acerca de uma visão de mundo" (Freud,1933/2010), resgatamos uma frase na qual Freud resume este sujeito sob tal condição-limite à possibilidade de existir e o que desta existência escapa à condição. Temos "Wo Es war, soll Ich werden" (Freud citado por Lacan 1965/1998, p. 878). A frase não conforta o leitor com pronomes definidos, o que nos ajudaria no terreno da tradução. Ainda assim, nos permitimos uma breve, mas pertinente revisão desta frase, evidenciando as seguintes traduções:

- "Là où c'était, Il me faut advenir", proposta por Lacan em "La Science et la Vérté" (1965/1966, p. 864).

- “Onde era o Id, há de ser o Eu" (Freud, 1933/2010, p. 223), tradução de Paulo César de Souza.

- "Ali onde se estava, ali como sujeito devo vir a ser”, proposta por Garcia-Roza (2009, p. 209).

Todas as traduções carregam a difícil tarefa de conciliar o rigor das normas gramaticais de duas línguas e a necessidade de fornecer, na medida do possível (ou do impossível), à sua língua materna, o peso afetivo da organização semântica que se experiencia e que a frase conseguiria transmitir na língua original.

Segundo Tavares (2010), a versão de Garcia-Roza, apesar de se distanciar, em parte, de uma tradução literal, não abre margem para o entendimento do Eu e do Id como entidades externas e distantes entre si. Aquela que seria uma possível interpretação terminaria por se distanciar ou culminaria em uma explicação rasa do que o autor desenvolveu até então em relação a tais instâncias. A nosso ver, Garcia-Roza e Lacan nos possibilitariam uma interpretação na qual esses "dois senhores" estão duplamente implicados, ou seja, uma implicação do sujeito no seu advir, uma dialética da alteridade de si que só é no a posteriori de si mesma.

Em Descartes, há uma relação direta entre o Eu que existe no ato de pensar que pensa, porém, na psicanálise, este Eu não é, um Eu que não está enquanto ato de pensar que pensa, uma vez que é implicado naquilo que é recalcado. Em Lacan (1957/1998) temos a subversão deste cogito na constituição de um sujeito dividido por estrutura. Ele o subverte em "penso onde não sou, logo sou onde não penso", e acrescenta: "eu não sou lá onde sou joguete de meu pensamento; penso naquilo que sou lá onde não penso pensar" (p. 521).

A partir da perspectiva do cogito, o sujeito cartesiano caberia nas formalizações da lógica proposicional, na condição trivial de suas premissas. Trabalhar sob esta perspectiva é um convite ao encontro com o que, do sujeito, lhe é estranho e familiar, o Unheimlich em Freud

2 "Lá onde isso estava, lá, como sujeito, devo [eu] advir" (Lacan, 1965/1998, p. 878).
(1919/2010), um paradoxo que o mantém na busca do saber de uma verdade sobre si. Nesta busca, a figura do clínico se destaca como aquele que detém o saber (Lacan, 2008), mas não só ele. Considerando os discursos que ocupam o lugar de saber sobre o sujeito da ciência na sociedade e para aproximamo-nos do recorte deste artigo, destacamos a seguir as formações discursivas médica e jurídica.

\section{Resenha crítica do texto da regulação brasileira de reprodução assistida}

$\mathrm{O}$ direito individual ao planejamento familiar e a infertilidade considerada um problema de saúde são condições ideais para o desenvolvimento de novas tecnologias reprodutivas. No Brasil, todos os procedimentos referentes à reprodução assistida (RA) são regulados por diretrizes propostas pelo Conselho Federal de Medicina (CFM) e reunidas no texto CFM n ${ }^{\circ} 2.168 /$ 2017. As diretrizes guiam as respostas dos clínicos, desde a queixa de infertilidade aos procedimentos em laboratório, buscando a melhor conciliação entre os princípios éticos da medicina, da jurisdição brasileira e das oportunidades que o mercado de novas tecnologias reprodutivas oferece.

O objetivo dessas diretrizes é controlar as práticas de uma oferta mercadológica que se dispõe a responder a demanda reprodutiva parental, que vai além da escolha dos materiais, da manipulação laboratorial e da reprodução humana. Ofertam-se, portanto, condições para a produção e manutenção de laços parentais a partir dos pressupostos do que lhes são essenciais.

Destacamos aqui trechos das diretrizes que regulam a utilização de materiais doados, ofertados como possibilidade de tratamento para a infertilidade, nas quais os sujeitos estão envolvidos em formas alternativas de participação da reprodução parental. Levantaremos questões sobre suas premissas e o que nelas sustenta o que podemos deduzir por filiação.

\section{Resolução do Conselho Federal de Medicina}

O CONSELHO FEDERAL DE MEDICINA . . . Resolve: Art. $1^{\circ}$ Adotar as normas éticas para a utilização das técnicas de reprodução assistida, anexas à presente resolução, como dispositivo deontológico a ser seguido pelos médicos. Art. $2^{\circ}$ Revogar a Resolução CFM n ${ }^{\circ} 2.121$, publicada do DOU de 24 de setembro de 2015, seção I, p. 117 e disposições em contrário. (Resolução CFM $\mathrm{n}^{\mathrm{o}} 2.168 / 2017$, p. 2$)^{3}$

Referente ao caráter deontológico da Resolução, não temos referências diretas aos pressupostos éticos utilizados

3 Recuperado de https://bit.ly/2XnJZZO 
para embasar algumas normas nem no código de ética médica, tampouco na resolução sobre a prática da RA.

Os efeitos de aplicação ainda são recentes e geram especulações relacionadas à eficiência e a consequência. Não existem mais que três gerações possibilitadas pelas técnicas de RA e há uma dificuldade prática do acesso a essas técnicas para o mapeamento dos efeitos das normas sobre a vida dos indivíduos que participaram desses métodos:

CONSIDERANDO a infertilidade humana como um problema de saúde, com implicações médicas e psicológicas, e a legitimidade do anseio de superá-la; CONSIDERANDO o aumento das taxas de sobrevida e cura após os tratamentos das neoplasias malignas, possibilitando às pessoas acometidas um planejamento reprodutivo antes de intervenção com risco de levar à infertilidade ...; CONSIDERANDO que o avanço do conhecimento científico já permite solucionar vários casos de problemas de reprodução humana. . . . (Resolução $\mathrm{CFM} \mathrm{n}^{\mathrm{0}} 2.168 / 2017$, p. 1$)^{4}$

Destacamos ainda que, em um cenário antecedente ao desenvolvimento de tais técnicas, os casos de infertilidade por idade avançada ou relação homoafetiva não eram considerados problema de saúde ou direito a ser conquistado. Por meio da RA, a reprodução ganha um novo status: o do direito de filho atrelado ao direito do planejamento familiar. $\mathrm{O}$ discurso sobre a produção de filho enquanto direito individual de cada sujeito fica claro quando a Resolução circunscreve os sujeitos aos quais as técnicas de reprodução são destinadas:

. . todas as pessoas capazes, que tenham solicitado o procedimento e cuja indicação não se afaste dos limites desta resolução . . . desde que os participantes estejam de inteiro acordo e devidamente esclarecidos sobre a mesma, de acordo com a legislação vigente. 2 - É permitido o uso das técnicas de RA para relacionamentos homoafetivos e pessoas solteiras, respeitando o direito da objeção de consciência do médico. (Resolução $\mathrm{CFM} \mathrm{n}^{\circ} 2.168 / 2017$, p. 4)

CONSIDERANDO que o pleno do Supremo Tribunal Federal, na sessão de julgamento de 5 de maio de 2011, reconheceu e qualificou como entidade familiar a união homoafetiva; CONSIDERANDO a necessidade de harmonizar o uso destas técnicas com os princípios da ética médica ... (Resolução CFM no 2.168/2017, p. 1) ${ }^{5}$

4 Recuperado de https://bit.ly/2XnJZZO

5 Recuperado de https://bit.ly/2XnJZZO
A queixa de infertilidade e a demanda de filho coincidem na clínica médica de RA, possibilitando ao clínico autentificar os pacientes na condição de futuros pais e mães do filho gerado. O conteúdo da Resolução compactua com a jurisdição na medida em que a produção de filho é direito de cada cidadão, independentemente de sua orientação sexual ou estado civil. O suporte legal já autentifica a filiação dos que assumem a demanda de filho.

Por outro lado, a RA também sustenta limites àqueles que desejam ter filhos, como a capacidade anatomofisiológica dos corpos envolvidos no processo, a qualidade dos materiais férteis para utilização, a tecnologia disponível, além do "acaso" da natureza, um limite desconhecido quando as tentativas de reprodução não obtiveram sucesso, sem que se saiba o porquê. Até aqui, a filiação parental parece prescindir da herança genética envolvida. Contudo tal concepção de filiação muda radicalmente diante de outros imperativos presentes na mesma Resolução.

1. A doação nunca terá caráter lucrativo ou comercial.

2. Os doadores não devem conhecer a identidade dos receptores e vice-versa.

3. A idade-limite para a doação de gametas é de 35 anos para mulheres e 50 anos para o homem.

4. Será mantido, obrigatoriamente, o sigilo sobre a identidade dos doadores de gametas e embriões, bem como dos receptores. Em situações especiais, as informações sobre doadores, por motivação médica, podem ser fornecidas exclusivamente para médicos, resguardando-se a identidade civil do doador.

5. As clínicas, centros ou serviços que empregam a doação devem manter, de forma permanente, um registro de dados clínicos de caráter geral, características fenotípicas e uma amostra de material celular dos doadores, de acordo com a legislação vigente.

6. Na região de localização da unidade, o registro dos nascimentos evitará que um(a) doador(a) tenha produzido mais que duas gestações de crianças de sexos diferentes em uma área de um milhão de habitantes. Um(a) mesmo(a) doador(a) poderá contribuir com quantas gestações forem desejadas, desde que em uma mesma família receptora.

7. A escolha dos doadores de oócitos é de responsabilidade do médico assistente. Dentro do possível, deverá garantir que o(a) doador(a) tenha a maior semelhança fenotípica e a máxima possibilidade de compatibilidade com a receptora.

8. Não será permitido aos médicos, funcionários e demais integrantes da equipe multidisciplinar das clínicas, unidades ou 
serviços participarem como doadores nos programas de RA.

9. É permitida a doação voluntária de gametas, bem como a situação identificada como doação compartilhada de oócitos em RA, em que doadora e receptora, participando como portadoras de problemas de reprodução, compartilham tanto do material biológico quanto dos custos financeiros que envolvem o procedimento de RA. A doadora tem preferência sobre o material biológico que será produzido. (Resolução CFM no $^{\circ}$ 2.168/2017, pp. 6-7) ${ }^{6}$

Não encontramos uma justificativa sobre a função do sigilo da identidade civil entre doador e receptor, mas apresentamos para a discussão o posicionamento de dois juristas em relação à obrigatoriedade do sigilo e manutenção do anonimato, no que desta regra toca a necessidade, em casos de utilização de materiais doados. O advogado dr. Eduardo de Oliveira Leite (1995) usa a distinção entre a genética e a filiação para justificar a necessidade do anonimato.

. . . doação de gametas não gera ao seu autor nenhuma consequência parental relativamente à criança daí advinda. A doação é abandono a outrem, sem arrependimento sem possibilidade de retorno. É medida de generosidade, medida filantrópica. Essa consideração é o fundamento da exclusão de qualquer vínculo de filiação entre doador e a criança oriunda da procriação. É, igualmente, a justificação do princípio do anonimato. . . O anonimato é a garantia da autonomia e do desenvolvimento normal da família assim fundada e também a proteção leal do desinteresse daquele que contribui na sua formação. (Leite, 1995, pp. 145-339 citado por Castro, 2007, p. 10)

O advogado dr. Paulo Luiz Netto Lôbo (2004) usa a distinção entre a genética e a filiação, mas, a partir do que se expõe na legislação, ele distingue o direito de conhecimento da origem genética e o direito à filiação. Além disso, ele questiona o anonimato partindo de um discurso preventivo compartilhado pela própria medicina, a saber, sobre o mapeamento e a prevenção de doenças genéticas.

O objeto da tutela do direito ao conhecimento da origem genética é a garantia do direito da personalidade, na espécie, direito à vida, pois os dados da ciência atual apontam para a necessidade de cada indivíduo saber a história de saúde de seus parentes biológicos próximos, para prevenção da própria vida. Não há necessidade de atribuição da paternidade para o exercício do direito da personalidade de conhecer, por exemplo, os

6 Recuperado de https://bit.ly/2XnJZZO ascendentes biológicos paternos do que foi gerado por doador anônimo de sêmen, ou do que foi adotado, ou concebido por inseminação artificial heteróloga. (Lôbo, 2004, pp. 53-54)

A análise das premissas relacionadas ao anonimato nos conduzirá à precisão referente ao lugar da herança genética em tais discursos, o que merece nossa atenção, pois ilustra bem o paradoxo na determinação filiatóriaparental nas formações discursivas com as quais trabalhamos. Buscaremos estabelecer, com base na lógica formal clássica, algumas formalizações das premissas extraídas dos discursos expostos. Implicamo-nos com o que podemos extrair dos argumentos apresentados pelos juristas e com o que, do texto regulador, nos é exposto como axioma.

\section{Proposta de formalização}

Tomaremos os argumentos em português e traduziremos para a linguagem artificial, objetivando analisar a validez das premissas destacadas. As letras dessa linguagem artificial fazem parte do alfabeto do Cálculo Quantificacional Clássico (CQC) e especificarão sobre as variáveis proposicionais possíveis de serem formalizadas. São elas: A, B, C, D, E e F; e seus símbolos conectivos: --> (Implicação), <--> (Dupla-implicação), \& (Conjunção), v (Disjunção), $\neg$ (Negação); ( ) (Parênteses) (Mortari, 2016, p. 69). O conceito de fórmula é tal como o usual e as fórmulas serão escritos por letras latinas.

Consideremos a premissa "Os doadores não devem conhecer a identidade dos receptores e vice-versa", que podemos representar por:

- Os doadores não devem conhecer a identidade dos receptores: $\neg \mathrm{E}$

- Os receptores não devem conhecer a identidade dos doadores: $\neg \mathrm{F}$

A justificativa do anonimato, dada pelo primeiro jurista ("O anonimato é a garantia da autonomia e do desenvolvimento normal da família. . .”), será tomada como as premissas:

- Anonimato é garantia de autonomia: A

- Anonimato é garantia do desenvolvimento normal da família: B

Para o primeiro jurista, o conhecimento da identidade civil entre doador e receptor de material influenciaria o "desenvolvimento normal" da família, isto é, a construção de seus laços parentais. Contudo o primeiro argumento também afirma que "a doação de gametas não gera ao seu autor nenhuma consequência parental".

Se em um momento ele dissocia genética $(G)$ e filiação (D), em outro a revelação do nome poria em 
questão a última. Não existe uma diferença clara entre o que se entende por filiação genética e filiação perante a esfera jurídica, nem o que leva a serem tratadas de formas distintas. Entretanto, se o lugar da filiação genética no autentificar da filiação fosse possível de se separar daquilo que a jurisdição concebe como filiação, nem o pai biológico (possível reivindicador da paternidade legal), nem os juristas teriam algo a dizer um para o outro. Não haveria questão. É possível sustentar, neste ponto, que a genética e a noção de filiação parental são implicadas duplamente:

$$
\text { - A genética e a filiação coincidem: } \mathrm{C}<->\mathrm{D}
$$

Apesar de o primeiro discurso ilustrar um posicionamento paradoxal referente à genética e à filiação parental, optamos por considerar as premissas que nele implicam sua proposta de justificar a pertinência do anonimato. Assim, a identidade civil influencia na filiação e a genética condiz com a filiação, ou seja, se "o anonimato é a garantia da autonomia e do desenvolvimento normal da família. .." e genética e filiação se coincidem, então "os doadores não devem conhecer a identidade dos receptores e vice-versa".

$$
\left((\mathrm{A} \& \mathrm{~B})^{\wedge}(\mathrm{C}<->\mathrm{D})\right)->(\neg \mathrm{E} \& \neg \mathrm{F})
$$

O segundo jurista se posiciona contra o anonimato, apoiando-se na concepção de filiação não atribuída à ascendência biológica: "Não há necessidade de atribuição da paternidade para o exercício do direito da personalidade de conhecer, por exemplo, os ascendentes biológicos paternos". Este segundo discurso se apresenta mais claro. Uma vez que a genética não condiz com a filiação, então o não anonimato não implica a não autonomia e desenvolvimento "normal" da família.

$$
\neg(\mathrm{C}<->\mathrm{D})-(\neg(\mathrm{E} \& \mathrm{~F})->\neg(\mathrm{A} \& \mathrm{~B}))
$$

A obrigatoriedade do anonimato é, para todos os efeitos, atribuída a dois propósitos que se relacionam entre si: (1) para resguardar o doador e o receptor de algo, referente à produção de filho e capaz de se perpetuar após o ato da doação. Caso consideremos o doador e o receptor/ casal receptor como sujeitos de alteridade no processo, admitimos que há algo deles que se perpetua, que ecoa nos discursos e compõe o laço parental, mesmo depois da utilização dos materiais férteis. Não é suficiente conceber o que se transmite por cogito pela explicação biológica, tampouco ignorar o que, da herança genética, nos diz sobre a subjetividade envolvida na escolha pelo médico, pelo método e pelas características desejadas, atribuídas ao doador do material. Desmente-se, portanto, o que concerne à dimensão do desejo, mas que é transmitido pelos significantes enredados na fantasia filiatória. (2) Para garantir que a relação entre sujeitos envolvidos no processo de RA (no ato de doar e receber) seja resumida aos objetos-células, controlados em laboratório e findada após a manipulação desses materiais.

O sujeito não é implicado na forma como a reprodução se deu, e sua alteridade no ato de doar ou receber os materiais férteis é desmentida. A subjetividade da construção filiatória se crê controlada pelo anonimato. Assim, diante de situações nas quais precisam ser utilizados materiais férteis doados, a necessidade do anonimato pode vir como precaução para algo que se perpetue desses atos reprodutivos e que não comprometa uma construção "não-natural" dos laços parentais.

\section{O paradoxo e seus diferentes destinos}

Levamos em conta o lugar central que as filiações ocupam na teoria psicanalítica, sobretudo na dialética envolvida na formação dos laços filiatórios. Não é suficiente contemplar o sujeito da clínica psicanalítica e sua estruturação psíquica partindo da estrutura lógica proposicional, mas é pertinente considerar o lugar do código genético na construção simbólica e imaginária desse laço parental, uma construção singular que localiza os participantes no enredo sobre suas origens.

Uma vez que a participação do código genético na filiação sob tais circunstâncias entra em questão, torna-se importante encará-lo além de uma premissa verdadeira ou falsa, para pensar a parentalidade em psicanálise. Logo, se quisermos formalizar a relação entre genética e filiação com o que a teoria psicanalítica nos fornece, teremos:

$\neg((\mathrm{C}<->\mathrm{D}) \mathrm{v} \neg(\mathrm{C}<->\mathrm{D})) \& \neg((\mathrm{A} \& \mathrm{~B}) \mathrm{v} \neg(\mathrm{A} \& \mathrm{~B}))$

Podemos ler como: "Não é o caso que a genética condiga ou não com a filiação e não é o caso que conhecer a identidade civil do doador influencie ou não influencie a filiação", uma formalização impossível ao crivo da lógica proposicional. O que possibilita a construção do laço parental coincide com o lugar onde o sujeito se coloca em relação ao desejo Outro, uma relação estranha e familiar (Unheimlich) de sua condição dividida, um paradoxo destino de sua anatomia psíquica, de estrutura paraconsistente.

Tratando-se de uma clínica de aposta no sujeito do inconsciente e tomando a máxima lacaniana "o inconsciente é estruturado como uma linguagem" (Lacan, 2008, p. 199), temos o seguinte destino ao paradoxo genético-filiatório: a filiação parental conta com a escrita genética do que se perpetua na reprodução, com a presença ausente desse doador, mas não pode ser resumida na trivialidade de suas premissas verdadeiras ou falsas.

O método de escuta da clínica psicanalítica recepciona um discurso sobre a filiação parental, no qual a verdade filiatória se torna possível sob uma relação êxtima do sujeito com o seu desejo, apostando 
na estrutura lógica paraconsistente de funcionamento do sujeito do inconsciente. A aposta do clínico não só expõe o sujeito da psicanálise como aquele cuja estrutura derroga o princípio da não-contradição, como também expõe a teoria psicanalítica como uma teoria na qual o inconsistente é estruturado logicamente por invariantes inconsistentes, mas não triviais.

A relação entre psicanálise e lógica justificou um estudo cuidadoso proposto por Jorge Forbes e Newton Carneiro Affonso da Costa no final dos anos 1980. Os autores sustentam a possibilidade de aplicação do estudo da lógica para pensar a psicanálise, tanto como instrumento heurístico para o esclarecimento de alguns aspectos da teoria quanto para formalizar certas invariantes dos relatos clínicos (Forbes \& Costa, 1987). No entanto o que presenciamos como destino do paradoxo genético-filiatório nas formações discursivas do campo caracteriza o encerramento de uma das premissas da antinomia, na condição de não-verdade, modalizado pela particularidade do paciente que o impossibilita de reproduzir a desejada filiação parental.

Em casos nos quais as famílias recebem materiais doados, o paradoxo genético-filiatório tem o seguinte destino: a obrigatoriedade do sigilo da identidade civil entre doadores e receptores desmente ${ }^{7}$ a participação de um terceiro ator na construção filiatória. Temos um destino que sustenta a genética como a verdade científica autenticadora da filiação parental, como se - e somente se -, na manutenção de um anonimato, o sujeito gerado pudesse desenvolver os enredos sobre sua origem com sua família, um sujeito livre de respostas, a saber, sobre o desejo do Outro, a extimidade de sua condição dividida ${ }^{8}$.

$\mathrm{O}$ anonimato como medida a ser seguida e o desmentido como qualidade presente no discurso são expressões de um campo às voltas com seu paradoxo, referentes ao que se toma como "a verdade" da origem parental, paradoxo inevitável e aparente nas novas possibilidades e ofertas de reprodução humana. Desmentir o que está presente nos arquivos das clínicas, no corpo do filho gerado e mesmo no que é dito (ou necessariamente "não-dito") deste terceiro(s) participante(s) ilustra a verdade como causa e puro movimento da condição faltosa por estrutura.

A necessidade do sigilo das identidades nos indica algo frágil nas filiações parentais com materiais doados, uma perspectiva que reforça a verdade da filiação parental na existência, ainda que mítica, do material genético dos pais. O que chamamos aqui de paradoxo genético-filiatório só é possível por um mito genéticofiliatório em questão, diante das novas possibilidades de compartilhamento da experiência reprodutiva.

O sigilo das identidades e o desmentir da participação permanente do doador na história

\footnotetext{
7 "Verleugnung. . . . Termo criado por Sigmund Freud*, em 1923" (Roudinesco \& Plon, 1998, p. 656).

8 "Como sendo esse lugar central, essa exterioridade íntima, essa extimidade, que é a Coisa” (Lacan, 1991, p. 173).
}

filiatória também podem ser compreendidos sob o princípio responsabilidade (Jonas, 1994), diante do paradoxo que as novas possibilidades reprodutivas evocam ao saber da clínica médica. A bioética em Jonas se aproxima de uma ética kantiana quando, em relação à prudência, evoca a dimensão da renúncia por meio de princípios que se obstinam autônomos e universais. Em "Fundamentação da metafísica dos costumes", de 1785, podemos extrair de Kant (2007) o imperativo categórico "devo proceder sempre de maneira que eu possa querer também que a minha máxima se torne uma lei universal" (p. 33).

Em Jonas (1994), somos apresentados à máxima "Age de tal maneira que os efeitos de tua ação sejam compatíveis com a permanência de uma vida humana autêntica" ou "não ponhas em perigo a continuidade indefinida da humanidade na Terra"(p. 46). A Ética em Jonas é, sem dúvidas, atravessada pela época na qual ele desenvolveu seus trabalhos (a maior parte deles durante a Guerra Fria) com o ônus de ter sido um discípulo de Heidegger. Sua ética toca em um ponto da própria existência humana, por perseguir uma moral que garanta existência humana na terra. Arriscamonos a dispor de uma leitura influenciada pela dialética hegeliana (na qual Heidegger tanto se debruçou) para entender este futuro não garantido enquanto Outro, tanto à dimensão de um não-ser como em um vir-a-ser (Hegel, 1807/2014).

Assim, Jonas implicaria o indivíduo da ação além da moral kantiana da "boa intenção humana". Ele salienta as consequências futuras dos atos, tratando de um ser que o é no seu porvir. O futuro dialético implica e responsabiliza o sujeito em seus atos no presente. Entretanto temos um sujeito doador em questão, cuja relação com as consequências do seu ato de doar são desmentidas. O que é perpetuado por meio do filho produzido e da filiação parental reproduzida se torna, portanto, uma presença inquietante, Unheimlich, estranha e, ao mesmo, tempo familiar.

Desmentir a presença do doador e sua relação com as consequências de seu ato pode ser ilustrado com: "Eu sei, mas mesmo assim" (Mannoni, 1973 citado por Alberti \& Martinho, 2013, p. 136) nós mantemos o sigilo como precaução ao desenvolvimento "normal" da família e para não desencorajar a doação dos materiais "; e também: "eu sei que existe um sujeito no ato da doação e recepção, mesmo assim, isso não tem qualquer implicação após o ato da doação e todo o processo de RA"; ou ainda; "Não é verdade que a participação destes sujeitos no processo permaneça após o processo de RA".

Com o conceito "desmentido" marcamos que a prudência de todo o processo não se concentra unicamente naqueles que produzirão o filho clinicamente, mas

\footnotetext{
9 Informalmente, comenta-se que, caso a doação não seja mais obrigatoriamente anônima, isso desencorajaria futuros doadores, pois os exporia a algum tipo de implicação pelo ato da doação e o que se perpetua com este: o filho.
} 
também naqueles que, com este filho, reproduzirão seus sonhos parentais. A responsabilidade desse doador é se manter anônimo e não exigir qualquer vínculo com o filho produzido, sob a condição de doador do material genético.

Todos os participantes compartilham eticamente do processo que se perpetua no corpo do filho gerado, mas também compartilham da perpetuação de um mito que diz que a genética concentra uma verdade original, o "cogito" genético que ancora a existência do homem. Sua origem é, portanto, um discurso passível de escrita e sua filiação parental é passível de autenticação científica.

$\mathrm{O}$ desmentir nos remete ao que Freud discorre sobre a relação entre o Perverso e a mulher, cujo fetiche é débito de uma fantasia infantil na construção da diferença sexual (aqueles que tinham pênis e foram castrados e aqueles que não foram). $\mathrm{O}$ que nos interessa é a lógica que esse fetiche ilustra em Freud, a lógica de um argumento perverso, que desmente a incompletude de seu objeto de desejo, elegendo, conforme as "leis do pensamento inconsciente" (Freud, 1927/2014, p. 305), um objeto ou parte do corpo como representante deste falo, desta completude que não se tem.

O falo em Lacan ganha destaque na condição de significante de exceção, que marca da incompletude fundadora do sujeito da ciência. Ele é o significante mestre cuja valoração só pode ser negativa, significante possibilitador do advir de um enredo simbólico e imaginário que reveste (não completamente) o conjunto "homem".

\section{Considerações finais}

Ainda que a clínica psicanalítica corresponda à continuidade da prática médica, consideramos suas diferenças metodológicas, além do manejo do paradoxo genético-filiatório. O lugar do genoma nas formações discursivas do campo da RA no Brasil é o da verdade originária, por meio do encerramento de uma das premissas da antinomia filiatória na condição desmentida.

A admissão de uma verdade paralela implica uma escuta clínica na qual a estrutura lógica paraconsistente é a mesma que forja seu objeto de análise. A clínica psicanalítica recepciona um discurso do sujeito do inconsciente, no qual a verdade filiatória é possível, na antinomia entre o sujeito e extimidade do desejo que o causa.

Considerar da estrutura lógica de funcionamento dos processos filiatórios para além da transmissão de códigos genéticos nos ajuda a repensar as possibilidades de construção de laços filiatórios parentais entre indivíduos que não compartilham o mesmo material genético, com efeitos nas formações discursivas no campo médico, jurídico e psicanalítico.

Além disso, repensar a lógica de fundamentação de uma verdade filiatória pode nos ajudar a entender a relação entre o acúmulo de materiais congelados (óvulo, sêmen ou embrião) e a demora com a qual eles são descartados, doados para pesquisa ou para outras famílias, destinos que dependem da autorização dos sujeitos de sua origem. Esta pode ser uma proposta de trabalho para outro artigo.

\section{Medically assisted reproduction: paradox, ethics, and destiny}

Abstract: This is a comparative study concerning the relation between the psychoanalytic clinic and the physician, referring to whom both serve, the paradox derived from their epistemological grounds, and the fate given to this paradox. We contextualize the discourses of the clinical field of reproductive medicine in Brazil, in particular the regulatory text on reproduction practices with donated materials and two criticisms arising from the legal sphere. In the first section, the comparison between clinical methods considers that, despite the sharing of common epistemological grounds, clinics conceive the logic of functioning of the one to whom they direct their practice in different ways. However, the current regulation of Medically Assisted Reproduction clinical practices in Brazil exposes a paradox pertaining to the process of parental affiliation, which implies different medical and psychoanalytical epistemological bases, affecting their practices. In the second part of the article, we compare the different destinations resulting from this paradox.

Keywords: science, psychoanalysis, logic, assisted reproduction, philosophy.

\section{Reproduction médicalement assistée : paradoxe, éthique et destin}

Résumé: Cet article à pour but construire une étude comparative entre la clinique psychanalytique et la clinique médicale, relatif à qui ils sont destinés, le paradoxe dérivé de leurs bases épistémologiques et le destin donné à ce paradoxe. Nous apportons au contexte les discours du domaine clinique de la médecine reproductive au Brésil, en particulier le texte réglementaire des pratiques de reproduction avec des matériaux donnés et deux critiques de la sphère juridique. Dans la première partie, la comparaison entre les méthodes cliniques considère que, malgré le partage de bases épistémologiques communes, les 
cliniques considèrent, de différentes manières, la logique du fonctionnement de celui à qui ils sont destinés à la pratique. Cependant, la réglementation actuelle des pratiques cliniques de Reproduction médicalement assistée au Brésil expose un paradoxe concernant le processus d'affiliation parentale, qui implique les bases épistémologiques de la médecine et de la psychanalyse, et influence leurs pratiques. Ce sera dans la deuxième partie de l'article que nous comparerons les différentes destinations données à ce paradoxe.

Mots-clés : science, psychanalyse, logique, reproduction assistée, philosophie.

\section{Reproducción médica asistida: paradoja, ética y destino}

Resumen: El objetivo de este artículo es construir un estudio comparativo entre la clínica psicoanalítica y la médica relacionada a quien destinan, la paradoja derivada de sus bases epistemológicas y el destino dado a esta paradoja. Ponemos en discusión los discursos del campo clínico de la medicina reproductiva en Brasil, en particular el texto regulador de las prácticas de reproducción con materiales donados y dos críticas del marco jurídico. En la primera parte, la comparación entre los métodos clínicos permite considerar que, a pesar de que se compartan bases epistemológicas comunes, las clínicas conciben de forma distinta la lógica de funcionamiento para aquel a quien destinan sus prácticas. Sin embargo, la actual regulación de las prácticas clínicas de reproducción asistida en Brasil presenta una paradoja relacionada al proceso de afiliación parental, lo cual relaciona las bases epistemológicas médicas y psicoanalíticas, con efectos sobre sus respectivas prácticas. En la segunda parte del artículo comparemos los diferentes destinos dados a esta paradoja.

Palabras clave: ciencia, psicoanálisis, lógica, reproducción asistida, filosofia.

\section{Referências}

Alberti, S., \& Martinho, M. H. (2013). Sexuação, desejo e gozo: entre a neurose e a perversão. Psicologia USP, 24(1), 119-142. Recuperado de https://bit.ly/2B3gG5P

Birman, J., \& Hoffmann, C. (2017). Lacan e Foucault: conjunções, disjunções e impasses. São Paulo, SP: Instituto Langage.

Castro, P. (2007). O direito à identidade genética versus o direito ao anonimato do doador do material genético na reprodução assistida (trabalho de Conclusão de Curso), Pontifícia Universidade Católica do Rio Grande do Sul, Porto Alegre, RS.

Descartes, R. (2002). Princípios da filosofia. Rio de Janeiro, RJ: Editora UFRJ. (Trabalho original publicado em 1644)

Descartes, R. (2005). Meditações metafísicas (M. E. A. P. Galvão, trad., 2a ed.). São Paulo, SP: Martins Fontes. (Trabalho original publicado em 1641)

Forbes, J. F., \& Costa, N. C. A. (1987). Sobre psicanálise e lógica. Recuperado de https://bit.ly/2yU65cX

Freud, S. (2010). O inquietante. In História de uma neurose infantil "O homem dos lobos", Além do princípio do prazer e outros textos (P. C. Souza, trad., Vol. 14, pp. 328-376). São Paulo, SP: Companhia das Letras. (Trabalho original publicado em 1919)

Freud, S. (2010). Novas conferências introdutórias à psicanálise: acerca de uma visão de mundo. In $O$ malestar na civilização, novas conferências introdutórias e outros textos (P. C. Souza, trad., Vol. 18, pp. 124-321).
São Paulo, SP: Companhia das Letras. (Trabalho original publicado em 1933)

Freud, S (2014). Fetichismo. In Inibição, sintoma e angústia, O futuro de uma ilusão e outros textos (P. C. Souza, trad., Vol. 17, pp. 302-310). São Paulo, SP: Companhia das Letras. (Trabalho original publicado em 1927)

Garcia-Roza, L. A. (2009). Freud e o inconsciente (24a ed.). Rio de Janeiro, RJ: Zahar.

Hegel, G. W. F. (2014). Fenomenologia do espirito (9a ed.). Petrópolis, RJ: Vozes. (Trabalho original publicado em 1807)

Jonas, H. (1994). Ética medicina e técnica (A. F. Cascais, trad.). Lisboa: Veja.

Kant, I. (2007). Fundamentação da metafísica dos costumes (P. Quintela, trad.). Lisboa: Edições 70.

Lacan, J.(1966). LaScience et la Vérité. In Écrits (pp. 855-877). Paris: Éditions du Seuil. (Trabalho original publicado em 1965)

Lacan, J. (1991). O seminário, livro 7: a ética da psicanálise, 1956-1980. Rio de Janeiro, RJ: Zahar.

Lacan, J. (1998). A instância da letra no inconsciente ou a razão desde Freud. In Escritos (V. Ribeiro, trad., pp. 496-536). Rio de Janeiro, RJ: Zahar. (Trabalho original publicado em 1957)

Lacan, J. (1998). A ciência e a verdade. In Escritos (V. Ribeiro, trad., pp. 869-892). Rio de Janeiro, RJ: Zahar. (Trabalho original publicado em 1965)

Lacan, J. (2008). O seminário, livro 11: os quatro conceitos fundamentais da psicanálise, 1953-1980. Rio de Janeiro, RJ: Zahar. 
Lôbo, P. L. N. (2004). Direito ao estado de filiação e direito à origem genética: uma distinção necessária. Revista Brasileira de Direito de Família, (27), 47-56.

Mortari, C. A. (2016). Introdução à lógica (2a ed.). São Paulo, SP: Editora Unesp.

Roudinesco, E., \& Plon, M. (1998). Dicionário de psicanálise. Rio de Janeiro, RJ: Zahar.
Tavares, P. H. M. B. (2010). A língua alemã em Freud: e eu com Isso? Recuperado de https://bit.ly/2U10QQ7

Recebido: $22 / 12 / 2017$

R1: $23 / 02 / 2019$

R2: $16 / 09 / 2019$

Aprovado: 17/05/2020 


\section{Errata}

No manuscrito "Reprodução medicamente assistida: paradoxo, ética e destino", DOI: http://dx.doi.org/10.1590/ 0103-6564e170147, publicado no periódico Psicologia USP, volume 31, página 5:

Onde se lia:

$\neg(\mathrm{C}<->\mathrm{D})-(\neg(\mathrm{E} \& \mathrm{~F})->\neg(\mathrm{A} \& \mathrm{~B}))$

\section{Leia-se:}

$\neg(\mathrm{C}<->\mathrm{D})->(\neg(\mathrm{E} \& \mathrm{~F})->\neg(\mathrm{A} \& \mathrm{~B}))$ 